\title{
GAMBARAN PERILAKU KESELAMATAN WISATA WAHANA AIR OLEH PENGELOLA DI TANJUNG BENOA
}

\author{
Nyoman Adi Arta ${ }^{1}$, Kadek Eka Swedarma ${ }^{2}$, Komang Menik Sri Krisnawati ${ }^{3}$ \\ ${ }^{1}$ Mahasiswa Program Studi Sarjana Keperawatan Fakultas Kedokteran Universitas Udayana \\ ${ }^{2,3}$ Staff Dosen Program Studi Sarjana Keperawatan Fakultas Kedokteran Universitas Udayana \\ Alamat Korespondensi: adiartha0405@gmail.comg
}

\begin{abstract}
Abstrak
Perilaku pengelola wisata wahana air dalam upaya keselamatan wisatawan merupakan sebuah perilaku yang melibatkan pengetahuan, sikap, dan tindakan pengelola wisata wahana air dalam upaya menjaga keselamatan wisatawan saat bemain wahana air. Keselamatan wisatawan sangat tergantung dari pengelola yang meliputi pengetahuan, sikap, dan tindakan. Tujuan dari penelitian ini yaitu untuk mengetahui gambaran pengetahuan, sikap, dan tindakan dari pengelola wisata wahana air di Tanjung Benoa dalam upaya menjaga keselamatan wisatawannya. Penelitian ini merupakan penelitian deskriptif dengan metode kuantitatif yang terdiri dari 38 sampel yang didapatkan melalui purposive sampling. Pengumpulan data dilakukan dengan cara menyebarkan kuesioner untuk mengetahui gambaran pengetahuan, sikap, dan tindakan. Berdasarkan hasil penelitian didapatkan hasil pada variabel pengetahuan memiliki persentase pengetahuan baik yaitu $86,8 \%$ dan pengetahuan cukup 13,2\%. Pada variabel sikap persentase responden yang memiliki sikap baik yaitu $86,8 \%$ dan sikap tidak baik $13,2 \%$. Responden pada variabel tindakan memiliki persentase tindakan baik yaitu $81,6 \%$ dan tindakan tidak baik $18,4 \%$. Jadi dapat disimpulkan bahwa pengelola wisata wahana air di Tanjung Benoa memiliki perilaku baik karena $81 \%$ lebih mendapatkan nilai baik dalam setiap variabel. Saran untuk pengelola wisata wahana air yaitu selalu memberikan pelatihan kepada semua pengelola supaya bisa mempertahankan dan meningkatkan perilaku dari pengelola.
\end{abstract}

Kata Kunci : Pengetahuan, Sikap, Tindakan, Wahana air

\begin{abstract}
Abstrak
The behavior of water sport tourism managers in the effort of tourist safety is a behavior which involves knowledge, attitudes, and actions of water sport tourism managers in an effort to maintain the safety of tourists when playing water sport. The safety of tourists depends on the manager, which includes knowledge, attitudes, and actions. The purpose of this study is to know the description of the knowledge, attitudes, and actions of water sport tourism managers in Tanjung Benoa in an effort to maintain tourist safety. This research is a descriptive study with a quantitative method consisting of 38 samples obtained through purposive sampling. Data collection is done by distributing questionnaires to find out the description of knowledge, attitudes, and actions. Based on the results of the study the results obtained on the knowledge variable has a percentage of good knowledge that is $86.8 \%$ and sufficient knowledge of $13.2 \%$. On the attitude variable the percentage of respondents who have good attitudes is $86.8 \%$ and bad attitude is $13.2 \%$. Respondents in the action variable had a percentage of good actions is $81.6 \%$ and bad actions $18.4 \%$. Therefor it can be concluded that the water sport tourism manager in Tanjung Benoa has good behavior because more than $81 \%$ get good grades in each variable. Suggestions for managers of water sport are consistent \& sustainable in conduct training to all managers in order to maintain and improve the behavior of managers.
\end{abstract}

Keywords: Knowledge, Attitude, Action, Water Sports 


\section{PENDAHULUAN}

Pariwisata merupakan kegiatan dengan melakukan perjalanan untuk mendapatkan kepuasan, kenikmatan, peningkatan pengetahuan, bekerja, berolahraga, bersantai dan lain-lain (Zalukhu \& Meyers, 2009). Sektor pariwisata merupakan salah diperkirakan akan menjadi sumber devisa utama bagi Indonesia. Data menunjukkan menunjukkan kunjungan wisata ke Indonesia mengalami peningkatan dari 11,51 juta kunjungan pada tahun 2016 menjadi 14,03 juta kunjungan di tahun 2017. Salah satu daerah yang menyumbangkan devisa terbesar pada sektor pariwisata yaitu pulau Bali (Kementerian Pariwisata RI, 2017).

Pulau Bali menjadi salah satu destinasi wisata manca negara. Kunjungan dari wisatawan manca negara dikatakan mengalami peningkatan sebesar $5,46 \%$ pada tahun 2018 dari tahun 2017. Wisatawan yang tercatat paling banyak mengunjungi Bali yaitu wisatawan yang berasal dari Tiongkok, Australia, India, dan Perancis (Badan Pusat Statistik Provinsi Bali, 2018). Daya tarik pariwisata Bali sangat tinggi, hal tersebut dikarenakan kebudayaan dan keindahan alam yang ada di Bali. Selain itu, Bali juga telah mengembangkan berbagai wahanawahana menarik yang dapat meningkatkan daya tarik wisatawan salah satunya wahana air (Dinas Pariwisata Buleleng, 2016).

Wahana air merupakan salah satu wahana yang banyak diminati karena memiliki tingkat tantangan tersendiri bagi peminatnya. Data dari National Water Safety Forum (2013) menyatakan bahwa partisipasi peserta dalam kegiatan wahana air termasuk perahu daya, berlayar, dan dayung. Wahana air yang paling diminati oleh wisatawan adalah kano dan kayak.
Peningkatan jumlah peminat
wisata air juga diikuti dengan
meningkatnya angka kecelakaan akibat
wisata air. Wira Water Sport Bali
(2019) menyatakan bahwa berdasarkan
data dari water sports accidents and statistics pada tahun 2012, tenggelam menjadi salah satu penyebab kematian akibat kecelakaan air di Amerika Serikat. Data dari WHO (2017) menyatakan bahwa terdapat 372.000 orang yang meninggal akibat tenggelam setiap tahun di seluruh dunia. Bhudiana (2014) menyatakan bahwa pada kasus kecelakaan di 24 pantai di Bali, khususnya pantai yang ada di wilayah Badung memiliki case fatality rate (CFR) pada tahun 2011 yaitu 4\%, tahun 2012 yaitu 9\%, tahun 2013 yaitu 3\%, tahun 2014 yaitu 4\%, tahun 2015 yaitu $5,8 \%$. CFR yang tidak stabil menunjukkan bahwa upaya yang dilakukan belum optimal untuk mencegah atau menurunkan risiko kecelakaan.

Pariwisata di Bali sudah mengembangkan tempat-tempat wahana air di berbagai wilayah seperti pantai Sanur, Nusa Penida, Buleleng dan Tanjung Benoa. Tanjung Benoa merupakan tempat yang paling banyak dikunjungi oleh wisatawan mancanegara maupun wisatawan lokal untuk bermain wahana air. Rata-rata kunjungan wahana air di Tanjung Benoa mencapai 300 orang pada hari normal dan lebih dari 400 orang di hari raya Wanaputra (2018). Angka kunjungan wisatawan yang tinggi di Tanjung Benoa juga meningkatkan risiko kecelakaan yang terjadi saat bermain wahana air.

Hasil studi pendahuluan dengan melakukan wawancara pada manajer lapangan salah satu penyedia wahana air di Tanjung Benoa mendapatkan hasil bahwa pihak manajemen tidak mencatat jumlah kejadian kecelakaan yang 
terjadi. Akan tetapi, pihak manajemen hanya mencatat kronologi setiap kejadian kecelakaan yang terjadi. Pihak manajemen juga menyatakan bahwa setiap tahunnya terdapat kecelakaan yang terjadi di Tanjung Benoa.

Kasus kecelakaan yang terjadi di Tanjung Benoa dapat berakibat pada penurunan jumlah kunjungan wisatawan apabila tidak dilakukan perbaikan manajemen untuk mencegah atau mengatasi kejadian tersebut. Angka kejadian kecelakaan tersebut dapat ditekan atau diturunkan dengan mengetahui cara penanganan awal pada kasus kecelakaan wahana air oleh petugas wahana. Selain itu, petugas wahana tersebut tidak mampu mengaplikasikan SOP yang telah ditetapkan dengan baik untuk menangani kecelakaan yang terjadi.

Dalam dunia kesehatan khususnya keperawatan, terdapat istilah keperawatan pariwisata yang artinya perawatan dan pemulihan pasien untuk membantu dalam uji tuntas pra keputusan dan konseling kesehatan perjalanan pasca keputusan. Selain itu keperawatan pariwisata juga meliputi promosi kesehatan, pencegahan penyakit, dan perawatan orang sakit, dan sekarat (Tompkins, 2010). Berdasarkan hal tersebut, peneliti tertarik untuk mengetahui gambaran perilaku pengelola wahana air terhadap upaya keselamatan wisatawan di Tanjung Benoa.

\section{METODE PENELITIAN}

$\begin{array}{cc}\text { Jenis } & \text { penelitian ini yaitu } \\ \text { penelitian } & \text { kuantitatif }\end{array}$ pendekatan deskriptif. Penelitian ini dilakukan di di PT Tirta Harum Tajung Benoa Nusa Dua Bali, karena PT Tirta Harum merupakan salah satu pengelola wahana air terbesar di Tanjung Benoa. Penelitian ini dilakukan pada tanggal 18 Mei hingga 31 Mei 2019.
Populasi target penelitian ini yaitu staff dive dan staff wahana air yang berjumlah 42 orang. Sampel penelitian ini berjumlah 38 orang yang dipilih berdasarkan penghitungan rumus dan dengan teknik purposive sampling. Kriteria inklusi penelitian ini yaitu staff yang berhubungan dengan pemandu wahana air, telah mendapat informasi mengenai penanganan kecelakaan air, dan bersedia menjadi responden. Kriteria eksklusi penelitian ini yaitu staff yang libur /cuti selama penelitian dilakukan dan mengundurkan diri sebagai responden.

Alat pengumpul data yang digunakan peneliti yaitu lembar kuesioner tentang pengetahuan, sikap, dan tindakan yang masing-masing terdiri dari 10 pernyataan. Uji validitas dan uji reliabilitas telah dilakukan untuk ketiga kuesioner tersebut. Hasil uji validitas pengetahuan memiliki rentang $r$ hitung dari 0,32 sampai 0,54 dan semua soal valid. Untuk soal di item sikap memiliki rentang nilai $\mathrm{r}$ hitung yaitu $0,32-0,72$ dan semua soal valid. Pada item tindakan memiliki rentang $\mathrm{r}$ hitung 0,34-1 dan semua soal valid. Pada uji reliabilitas item pengetahuan memiliki nilai $\alpha=0,64$, item sikap $\alpha=$ 0,76 dan item tindakan $\alpha=0,74$ semua item memiliki $\alpha \geq 0,6$ yang berarti semua item reliabel.

Pengumpulan data dilakukan setelah mendapat izin ke pihak-pihak terkait dan telah mendapat surat laik etik dari Komisi Etika Penelitian FK Unud/RSUP Sanglah.

Data dikumpulkan dengan memberikan kuesioner kepada sampel penelitian. Pengisian kuesioner selama penelitian dibantu oleh peneliti. Data yang telah terkumpul dilakukan tabulasi kemudian dianalisis.

Analisis data yang digunakan yaitu analisis statistik deskriptif untuk mengetahui tendensi sentral yaitu 
median dan disajikan dalam bentuk

HASIL PENELITIAN tabel.

Tabel 1.

Persentase gambaran pengetahuan pengelola wisata wahana air di Tanjung Benoa berdasarkan karakteristik usia, tingkat pendidikan dan masa bekerja

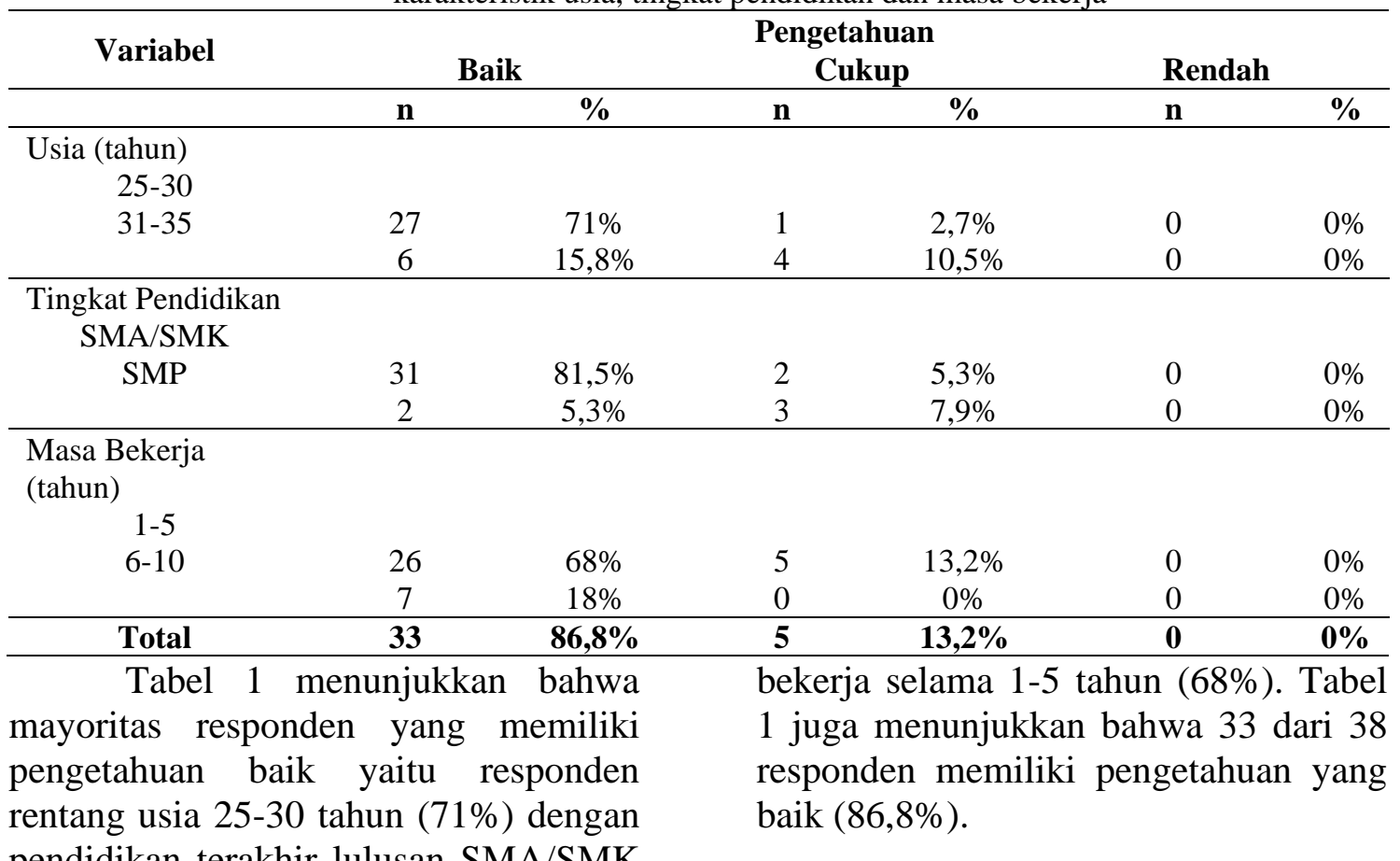
pendidikan terakhir lulusan SMA/SMK $(81,5 \%)$ dan dengan pengalaman

Tabel 2

Persentase gambaran sikap pengelola wisata wahana air di Tanjung Benoa berdasarkan karakteristik usia, tingkat pendidikan dan masa bekerja

\begin{tabular}{ccccc}
\hline Karakteristik & & Baik & Sikap & Tidak baik \\
\hline Usia (tahun) & N & \% & n & \% \\
$25-30$ & 24 & $63,1 \%$ & & $10,5 \%$ \\
$31-35$ & 9 & $26,7 \%$ & 1 & $2,7 \%$ \\
\hline Tingkat Pendidikan & & & & \\
SMA/SMK & 29 & $76,3 \%$ & 4 & $10,5 \%$ \\
SMP & 4 & $10,5 \%$ & 1 & $2,7 \%$ \\
\hline Masa Bekerja (tahun) & & & & $13,2 \%$ \\
6-10 & 26 & $68,4 \%$ & 5 & $0 \%$ \\
\hline Total & 7 & $18,4 \%$ & 0 & $13,2 \%$ \\
\hline
\end{tabular}

Tabel 2 menunjukkan bahwa

nilai sikap yang baik mayoritas dimiliki oleh rentang usia 25-30 tahun $(63,1 \%)$, dengan tingkat pendidikan SMA/SMK $(76,3 \%)$, dan memiliki masa kerja 1-5 tahun (68,4\%). Tabel 2 juga menunjukkan bahwa 33 dari 38 responden memiliki nilai sikap yang baik $(86,8 \%)$. 
Tabel 3

Persentase gambaran tindakan pengelola wisata wahana air di Tanjung Benoa berdasarkan karakteristik usia, tingkat pendidikan dan masa bekerja

\begin{tabular}{|c|c|c|c|c|}
\hline \multirow{3}{*}{ Karakteristik } & \multicolumn{4}{|c|}{ Tindakan } \\
\hline & \multicolumn{2}{|c|}{ Baik } & \multicolumn{2}{|c|}{ Tidak baik } \\
\hline & $\mathbf{n}$ & $\%$ & $\mathbf{n}$ & $\%$ \\
\hline Usia (tahun) & & & & \\
\hline $25-30$ & 27 & $71 \%$ & 1 & $2,7 \%$ \\
\hline $31-35$ & 4 & $10,5 \%$ & 6 & $15,8 \%$ \\
\hline $\begin{array}{r}\text { Tingkat Pendidikan } \\
\text { SMA/SMK }\end{array}$ & & & & \\
\hline SMP & $\begin{array}{c}27 \\
4\end{array}$ & $\begin{array}{c}71 \% \\
10,5 \%\end{array}$ & $\begin{array}{l}6 \\
1\end{array}$ & $\begin{array}{c}15,8 \% \\
2,7 \%\end{array}$ \\
\hline
\end{tabular}

Masa Bekerja (tahun)

$1-5$

$6-10$

Total

$65,7 \%$

$\begin{array}{lll}15,8 \% & 1 & 2,7 \%\end{array}$

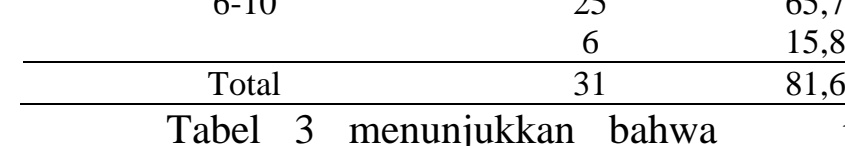

sebagian besar responden yang memiliki nilai tindakan yang baik yaitu responden dengan rentang usia 25-30 tahun $(71 \%)$, dengan tingkat pendidikan SMA/SMK (71\%), dan dengan masa kerja 1-5 tahun $(65,7 \%)$. Tabel 3 juga menunjukkan bahwa 31 dari 38 responden memiliki nilai tindakan yang baik $(81,6 \%)$

\section{PEMBAHASAN}

Hasil penelitian ini menunjukkan sebagian besar responden memiliki pengetahuan yang tergolong baik. Tingginya angka pengetahuan yang dimiliki pengelola wisata wahana air di Tanjung Benoa sejalan dengan sebuah jurnal dengan peneliti Moran et al (2011) yang menjelaskan untuk menyederhanakan penyampaian pesan keselamatan yang dipromosikan ke seluruh dunia, 18 ahli dari 12 negara membentuk satuan tugas International Task Force on Open Water Drowning Prevention (ITFDP) dan menerbitkan 16 pesan keselamatan dalam berwisata di air.

Informasi atau pelatihan yang diberikan diantaranya yaitu pengawasan terhadap wisatawan yang sedang bermain wahana air, pelatihan CPR, dan penggunaan jaket pelampung. Pelatihan ini bertujuan untuk mengatasi masalah kecelakaan pada wisata air dengan mempromosikan keselamatan wisata air melalui pendidikan masyarakat, kebijakan, dan perubahan lingkungan. Di Indonesia, khususnya di Bali sudah dilakukan pelatihan dan pendidikan keselamatan wisata air kepada pengelola atau pengawas dalam bermain wisata wahana air. Pengelola di Tanjung Benoa telah melakukan pelatihan kepada stafnya setiap 1 atau 2 tahun sekali untuk meningkatkan skill dan pengetahuan yang dimiliki oleh stafnya.

Berdasarkan hasil penelitian didapatkan nilai $13,2 \%$ yang memiliki pengetahuan cukup pada rentang usia 31-35 tahun, dengan pendidikan SMP. Hal ini sejalan dengan penelitian Suherlin (2010) yang menyatakan bahwa semakin bertambahnya usia maka terjadi penurunan kemampuan seseorang dalam menerima informasi yang menyebabkan pengetahuannya kurang. Herlina (2016) menyatakan bahwa tingkat pendidikan memiliki hubungan yang bermakna dengan pengetahuan karena pendidikan merupakan upaya pengajaran dan pelatihan yang dapat mengubah pola pikir sehingga semakin tinggi 
pendidikan, pengetahuan juga semakin tinggi. Akan tetapi, pengetahuan yang cukup juga terbanyak dimiliki oleh responden dengan masa kerja 1-5 tahun. Penelitian yang dilakukan oleh Rahayu (2010) menyatakan bahwa lingkungan dan waktu bekerja dapat meningkatkan pengalaman, sehingga semakin lama masa kerja, semakin banyak pengalaman yang dimiliki sehingga pengetahuannya juga meningkat.

Sikap merupakan respon seseorang yang masih tertutup terhadap rangsangan atau stimulus yang diterima baik berbentuk positif atau negative (Notoatmodjo, 2012). Hasil penelitian ini menunjukkan bahwa stimulus yang diterima oleh responden mengarah ke stimulus positif karena peningkatan pengetahuan berupa informasi dan skill dapat mempengaruhi sikap sebagian besar responden yang memiliki nilai sikap baik.

Hasil karakteristik responden menunjukkan sebagian besar responden dengan nilai sikap baik dimiliki oleh responden dengan masa kerja 1-5 tahun. Masa kerja dapat menjadi salah satu faktor yang mempengaruhi sikap karena masa kerja dapat menjadi dasar pembentukan pengalaman yang dapat meninggalkan kesan yang kuat sehingga pembentukan sikap menjadi lebih mudah karena melibatkan emosional (Azwar, 2013). Selain itu, berdasarkan karakteristik usia, responden yang memiliki sikap baik berada pada rentang usia 25-30 tahun. Penelitian Zuchdi (2014) menyatakan bahwa terdapat 3 komponen yang dapat membentuk sikap yaitu kognitif, afektif, dan konatif. Responden pada rentang usia 25-30 tahun memiliki komponen kognitif atau memiliki pengetahuan yang baik. Pengetahuan yang baik akan mempengaruhi seseorang dalam mengambil sikap. Sedangkan pada karakteristik tingkat pendidikan, responden yang memiliki sikap baik yaitu responden lulusan SMA/SMK, namun responden yang memiliki sikap tidak baik juga responden lulusan SMA/SMK. Hal ini menunjukkan tingkat pendidikan tidak terlalu mempengaruhi sikap dari pengelola wisata wahana air.

Hasil penelitian menunjukkan sebagian besar responden memiliki nilai tindakan yang baik. Ketiga hasil penelitian yang meliputi pengetahuan, sikap dan tindakan mengarah pada kategori positif yang lebih mendominasi. Penelitian yang dilakukan oleh Afianto \& Dewi (2016) menyatakan bahwa pengetahuan dapat mempengaruhi sikap kerja secara signifikan tetapi sikap belum merupakan suatu tindakan atau aktivitas, tetapi masih merupakan predisposisi suatu perilaku. Pengetahuan berpengaruh terhadap respon tentang bahaya sekitar, manfaat, fungsi alat dan prosedur dalam melakukan wisata wahana air. Sedangkan sikap mempengaruhi tindakan yang dalam hal ini adalah tindakan yang diberikan dalam upaya keselamatan wisatawan saat bermain wisata wahana air.

Usia responden yang memiliki nilai tindakan tidak baik yaitu pada rentang usia 31-35 tahun. Usia yang menua akan mempengaruhi kondisi fisik dan psikologis sehingga akan berpengaruh pada pengetahuan yang dimiliki, pengetahuan yang kurang akan mempengaruhi pengambilan sikap. Sikap yang tidak baik dapat menyebabkan pengambilan tindakan yang tidak baik juga. Selain itu, hasil penelitian menunjukkan tindakan yang tidak baik dimiliki oleh responden dengan masa kerja 1-5 tahun dan juga masa kerja 6-10 tahun. Masa kerja atau pengalaman juga mempengaruhi seseorang dalam pengambilan tindakan 
maka dari itu kurangnya pengalaman yang dimiliki oleh seseorang dengan suatu objek, cenderung akan mendorong perilaku yang negatif (Azwar, 2010). Hasil penelitian juga menunjukkan responden yang memiliki tindakan baik dan tidak baik terbesar pada tingkat SMA/SMK. Tindakan negatif juga dipengaruhi oleh orang lain yang dianggap penting (Azwar, 2010). Pada penelitian ini jumlah responden pada tingkat SMA/SMK lebih banyak daripada tingkat SMP maka dari itu apabila ada tindakan negatif yang dilakukan oleh kelompok mayoritas, maka akan ada seseorang dari kelompok yang sama mengikuti.

\section{KESIMPULAN DAN SARAN}

Penelitian ini menunjukkan bahwa sebagian besar staff pengelola wisata wahana air di Tanjung Benoa memiliki pengetahuan yang baik $(86,8 \%)$, memiliki sikap yang baik $(86,8 \%)$, dan memiliki perilaku yang baik $(81 \%)$.

Penelitian ini memiliki beberapa keterbatasan sehingga peneliti menyarankan kepada peneliti selanjutnya agar menambah jumlah dan sasaran perusahaan wahana air agar sampel lebih beragam. Selain itu, peneliti selanjutnya juga dapat meneliti terkait perilaku wisatawan yang menggunakan wisata wahana air. Petugas kesehatan khususnya perawat juga diharapkan melakukan upaya yang dapat meningkatkan pengetahuan masyarakat sekitar khususnya masyarakat di sekitar Tanjung Benoa terkait dengan keselamatan dalam wisata wahana air.

\section{DAFTAR PUSTAKA}

Afianto, M. \& Dewi. (2016). The correlation between knowledge and attitude with action of workers in working accordance to safety sign boards installed. Universitas Jember. Diakses dari: http://repository.unej.ac.id.

Azwar S. (2013). Sikap Manusia: Teori dan Pengukurannya. Yogyakarta: Pustaka Pelajar.

Badan Pusat Statistik Provinsi Bali. (2018). Kedatangan wisatawan mancanegara (wisman) ke Bali mencapai 624.366 kunjungan atau naik 14,66 persen (month to month). Diakses dari https://bali.bps.go.id/

Bhudiana. (2014). Profil Kesehatan Dinas Kabupaten Badung tahun 2014. Dinas Kesehatan.

Dinas Pariwisata Buleleng. (2016). Sekilas wawasan tentang pengertian pariwisata dan wisata-wisatanya. Diakses dari: https://dispar.bulelengkab.go.id

Herlina, S. (2016). Karakteristik dengan tingkat pengetahuan ibu postpartum tentang perawatan masa nifas di ruang Camar I Rumah Sakit Umum Daerah Arifin Achmad Pekanbaru. Universitas Sumatra Utara. Diakses dari: http://repository.usu.ac.id.

Kementerian Pariwisata RI. (2017). Kunjungan wisatawan tahun 2008-2016. Jakarta. Pusat Data dan Informasi Kementerian Pariwisata.

Moran, et al. (2011). Where the evidence and expert opinion meet: a review of openwater recreational safety messages. International Journal of Aquatic Research and Education; 5(3). Diakses dari: https://scholarworks.bgsu.edu.

Nasional Water Safety Forum. (2013). Watersports participation surges to highest evel. Retrieved from: https://nationalwatersafety.com

Notoatmodjo, S. (2012). Promosi kesehatan dan ilmu perilaku. Jakarta: Rineka Cipta.

Rahayu. (2010). Teori Proses Menua dan Permasalahannya. Diakses dari: http://s1 keperawatan.umm.ac.id/files/fi le/Teori\%20Proses\%20Menua\%20dan \%20P.pdf

Suherlin I. (2010). Hubungan karakteristik responden dengan tingkat pengetahuan responden tentang gaya hidup yang mempengaruhi infertil di lingkungan III Kelurahan Labuhan Deli Kecamatan Medan Marelan Tahun 2009. (Skripsi). Universitas Sumatera Utara.

Tompkins, J.A. (2010). Medical tourism and facilities planning. New York: Wiley. 
Wanaputra. (2018). Kunjungan ke Tanjung Benoa meningkat. Diakses dari ://www.nusabali.com

WHO (2017). Cardiovascular diseases (CVDs). Retrieved from: http://www.who.int/mediacentre/factsh eets.

Wira Water Sport Bali. (2019). Water sports Tanjung Benoa dan pilihan aktivitas. Diakses dari: https://www.water-sportbali.com/watersport-tanjung-benoa.

Zalukhu, S. \& Meyers, K. (2009). Panduan Dasar Pelaksanaan Ekowisata. Jakarta: Unesco Office.

Zuchdi, D. (2014). Pembentukan Sikap. Cakrawala pendidikan. Diakses dari: https://media.neliti.com. 